\title{
Reactive Blue 2 Induces Calcium Oscillations in HeLa Cells
}

\author{
Akico OKUDA, Kishio FURUYA*, and Toshikazu KIYOHARA \\ Department of Applied Biology, Kyoto Institute of Technology, \\ Matsugasaki, Kyoto, 606-8585 Japan; and \\ * ICORP Cell-Mechanosensing Project, JST, Nagoya University School of Medicine, \\ Tsurumai, Nagoya, 466-8550 Japan
}

\begin{abstract}
Reactive Blue 2 (RB), which is used as an ATP receptor antagonist, induced $\mathrm{Ca}^{2+}$ oscillations in HeLa cells. RB-induced $\mathrm{Ca}^{2+}$ oscillations were abolished in $\mathrm{Ca}^{2+}$-free solution. $\mathrm{RB}$, however, did not affect $\mathrm{Ca}^{2+}$ influx measured by $\mathrm{Mn}^{2+}$ quenching. The PLC cascade and intracellular $\mathrm{Ca}^{2+}$ release were involved as $\mathrm{U} 73122$ and
\end{abstract}

thapsigargin inhibited $\mathrm{RB}$-induced $\mathrm{Ca}^{2+}$ oscillations. $\mathrm{RB}$ enhanced a $\mathrm{Ca}^{2+}$ response to histamine that is linked to the PLC cascade. RB may activate the PLC cascade in an extracellular $\mathrm{Ca}^{2+}$-dependent manner and induce $\mathrm{Ca}^{2+}$ oscillations. [Japanese Journal of Physiology, 51, 389-393, 2001]

Key words: Reactive Blue 2, calcium oscillations, HeLa cells.

Calcium ion is an intracellular second messenger important for cellular functions in a variety of cells. In many cell types, transient and repetitive increases in the intracellular $\mathrm{Ca}^{2+}$ concentration $\left(\left[\mathrm{Ca}^{2+}\right]_{\mathrm{i}}\right)$ are observed upon stimulation by agonists. These phenomena are called $\mathrm{Ca}^{2+}$ oscillations. They are thought to substitute for the prolonged rise of $\left[\mathrm{Ca}^{2+}\right]_{\mathrm{i}}$, which is harmful to cells, and to work as frequency-modulation (FM) signals [1]. $\mathrm{Ca}^{2+}$ oscillations have been implicated in the control of various cellular functions such as gene expression $[2,3]$, enzyme activity in hepatocytes [4], and ciliary activity in airway epithelia [5]. However, the details of these mechanisms and functions are still unclear.

HeLa cells, a non-excitable epithelial cell line, are often used to investigate the mechanisms of intracellular $\mathrm{Ca}^{2+}$ signaling such as $\mathrm{Ca}^{2+}$ responses to hormones and $\mathrm{Ca}^{2+}$ oscillations. Histamine induces a $\mathrm{Ca}^{2+}$ response followed by $\mathrm{Ca}^{2+}$ oscillations in HeLa cells via the activation of G-protein, PLC (phospholipase $\mathrm{C}$ ) cascade, and $\mathrm{IP}_{3}$ receptors on the endoplasmic reticulum (ER) [6-8]. Histamine-induced $\mathrm{Ca}^{2+}$ oscillations are primarily caused by $\mathrm{Ca}^{2+}$ release from the $\mathrm{ER}$, but they also require $\mathrm{Ca}^{2+}$ entry to maintain or modulate $\mathrm{Ca}^{2+}$ oscillations $[7,8]$.
Reactive Blue 2 (RB) has been used as an antagonist of ATP receptors (P2-type purinergic receptors) $[9,10]$. RB, however, is a histochemical dye containing anthraquinone and has been reported to have other effects on cells and enzymes. RB inhibited GABA, glutamate [11], and NMDA [12] receptor channels; volume sensitive $\mathrm{Cl}^{-}$channels [13]; a thylakoid protein kinase [14]; and a certain dehydrogenase [15].

Here we found that the application of RB induced $\mathrm{Ca}^{2+}$ oscillations in HeLa cells. We also found that RB-induced $\mathrm{Ca}^{2+}$ oscillations had unique characteristics different from the other receptor-activated $\mathrm{Ca}^{2+}$ oscillations reported in HeLa cells [6-8].

\section{Materials and Methods}

HeLa cells were grown in DME/F12 (SIGMA, MO, USA) supplemented with $10 \%$ fetal bovine serum, 50 units $/ \mathrm{ml}$ penicillin, and $50 \mu \mathrm{g} / \mathrm{ml}$ streptomycin. Cells were cultured on glass coverslips $(25-\mathrm{mm}$ diameter, MATSUNAMI \#1) in a humidified atmosphere (5\% $\mathrm{CO}_{2}, 95 \%$ air) at $37^{\circ} \mathrm{C}$.

To introduce fura- 2 into the cells, they were incubated with $2 \mu \mathrm{M}$ fura-2 AM (acetoxymethyl ester; Dojindo, Kumamoto, Japan) and $0.2 \%$ cremophor EL (SIGMA) for $50 \mathrm{~min}$ at $37^{\circ} \mathrm{C}$. Coverslips bearing the

Received on January 26, 2001; accepted on April 25, 2001

Correspondence should be addressed to the present address: Akico Okuda, Department of Biophysical Engineering, Graduate School of Engineering Science, Osaka University, Toyonaka, 560-8531 Japan. Tel: +81-6-6850-6541, Fax: +81-6-6850-6557, E-mail: okuda@bpe.es.osaka-u.ac.jp 
cells were then placed in a chamber on the stage of an inverted epifluorescence microscope (Olympus IMT2RFL) to which was attached a xenon lamp. The chamber was continuously perfused. The normal medium consisted of (in mM) $\mathrm{NaCl} \mathrm{152,} \mathrm{KCl} 5.4, \mathrm{CaCl}_{2} 1.8$, $\mathrm{MgCl}_{2}$ 0.8, glucose 5.6, HEPES 10 (pH 7.4). The composition of the $\mathrm{Ca}^{2+}$-free solution was (in $\mathrm{mM}$ ) $\mathrm{NaCl} 152, \mathrm{KCl} 5.4, \mathrm{MgCl}_{2}$ 0.8, EGTA 0.5, glucose 5.6, HEPES 10 (pH 7.4). As stock solutions (100 $\mathrm{mM}$ ), Reactive Blue 2 (RBI, MA, USA), histamine (SIGMA), $\mathrm{LaCl}_{3}$ and $\mathrm{MnCl}_{2}$ were dissolved in water, and thapsigargin (SIGMA), U73122 (RBI), and U73343 (RBI) in DMSO. Each drug was diluted with the corresponding medium. Before the solution of the stimulants (1-2 ml) was applied to the chamber, perfusion was stopped and the medium was aspirated so that only a thin layer of the medium (less than $100 \mu$ l) remained in the bath chamber. Restarting perfusion washed out the stimulants.

Changes in $\left[\mathrm{Ca}^{2+}\right]_{\mathrm{i}}$ were measured with an image analysis system, ARGUS-50/CA (Hamamatsu Photonics), described previously [16]. All experiments were done at room temperature (about $24^{\circ} \mathrm{C}$ ).

\section{Results and Discussion}

Properties of RB-induced $\mathrm{Ca}^{2+}$ oscillations.

Within a few minutes after the application of Reactive Blue 2 (RB; $100 \mu \mathrm{M}), \mathrm{Ca}^{2+}$ oscillations were induced in HeLa cells (Fig. 1, A and B). Usually, agonist-induced $\mathrm{Ca}^{2+}$ responses consist of two phases, a first transient response and a second sustained increase. In many cases, $\mathrm{Ca}^{2+}$ oscillations occur at the second phase after the first transient response. However, RBinduced $\mathrm{Ca}^{2+}$ oscillations occurred without any first transient response or any sustained increase in $\left[\mathrm{Ca}^{2+}\right]_{\mathrm{i}}$ (Fig. 1B). The interval of the oscillations was a few minutes. In some cases, $\mathrm{Ca}^{2+}$ oscillations persisted for over $30 \mathrm{~min}$. The oscillations were terminated by washout of $\mathrm{RB} . \mathrm{Ca}^{2+}$ oscillations occurred in individual cells and did not propagate to neighboring cells (Fig. 1A).

The induction of $\mathrm{Ca}^{2+}$ oscillations by $\mathrm{RB}$ was dosedependent. The percentage of cells that showed oscillations increased with the concentration of RB (Fig. 1C). At $100 \mu \mathrm{M}$, almost all cells exhibited $\mathrm{Ca}^{2+}$ oscillations in response to RB. The amplitude of the oscillations did not change remarkably with the dose, while the number of oscillating cells increased and the interval of the oscillations was shortened as the dose was increased. At higher doses (300 to $500 \mu \mathrm{M}), \mathrm{RB}$ induced a sustained increase in $\left[\mathrm{Ca}^{2+}\right]_{\mathrm{i}}$ in some cells. We used $100 \mu \mathrm{M} \mathrm{RB}$ to stimulate $\mathrm{Ca}^{2+}$ oscillations in subsequent experiments.
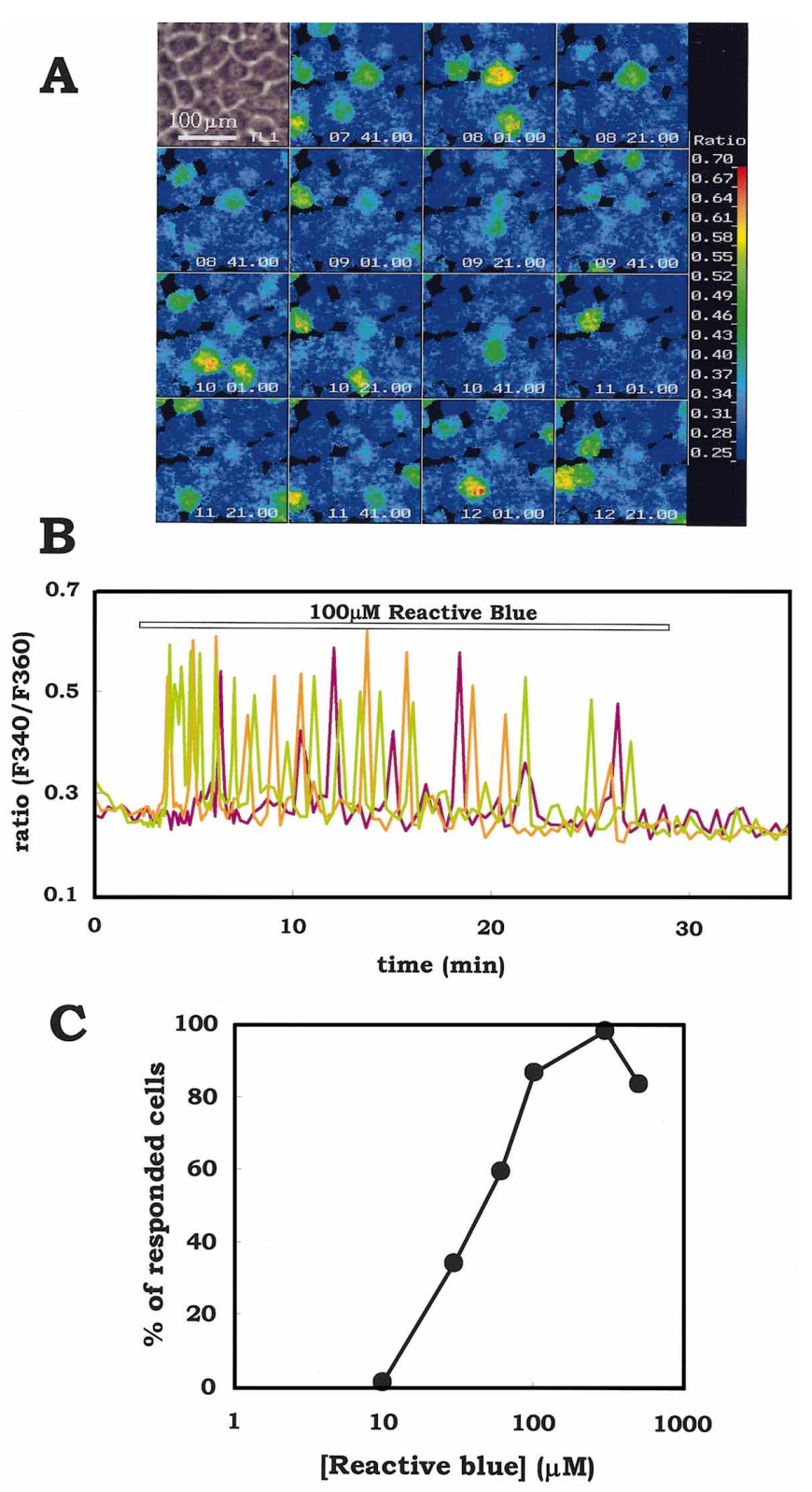

Fig. 1. $\mathrm{Ca}^{2+}$ oscillations induced by $\mathrm{RB}$ in HeLa cells. Reactive Blue 2 (RB; $100 \mu \mathrm{M})$ induced $\mathrm{Ca}^{2+}$ oscillations in almost all cells we measured (878 of 1,008 cells from 9 experiments). A: Spatial changes of $\mathrm{Ca}^{2+}$ oscillations. The top-left frame shows a phase contrast image of a monolayer of HeLa cells. Images of the fura-2 fluorescence ratio $\left(F_{340} / F_{360}\right)$ at $7 \mathrm{~s}$ intervals after the stimulation of RB are arranged from left to right and top to bottom. B: Temporal changes of $\mathrm{Ca}^{2+}$ oscillations. Typical traces of $\mathrm{Ca}^{2+}$ oscillations induced by RB $(100 \mu \mathrm{M})$ in 3 cells are shown. C: Dose response relationship of $\mathrm{RB}$. The percentage of cells that responded to $\mathrm{RB}$ was plotted against each concentration of RB. Each data point was the average of over 224 cells from 2 or 3 experiments.

Effects of extracellular $\mathrm{Ca}^{2+}$. In $\mathrm{Ca}^{2+}$-free solution (CFS), the application of $\mathrm{RB}$ induced no $\mathrm{Ca}^{2+}$ response and a re-addition of $\mathrm{Ca}^{2+}$ initiated $\mathrm{Ca}^{2+}$ oscillations (Fig. 2A). RB-induced $\mathrm{Ca}^{2+}$ oscillations 

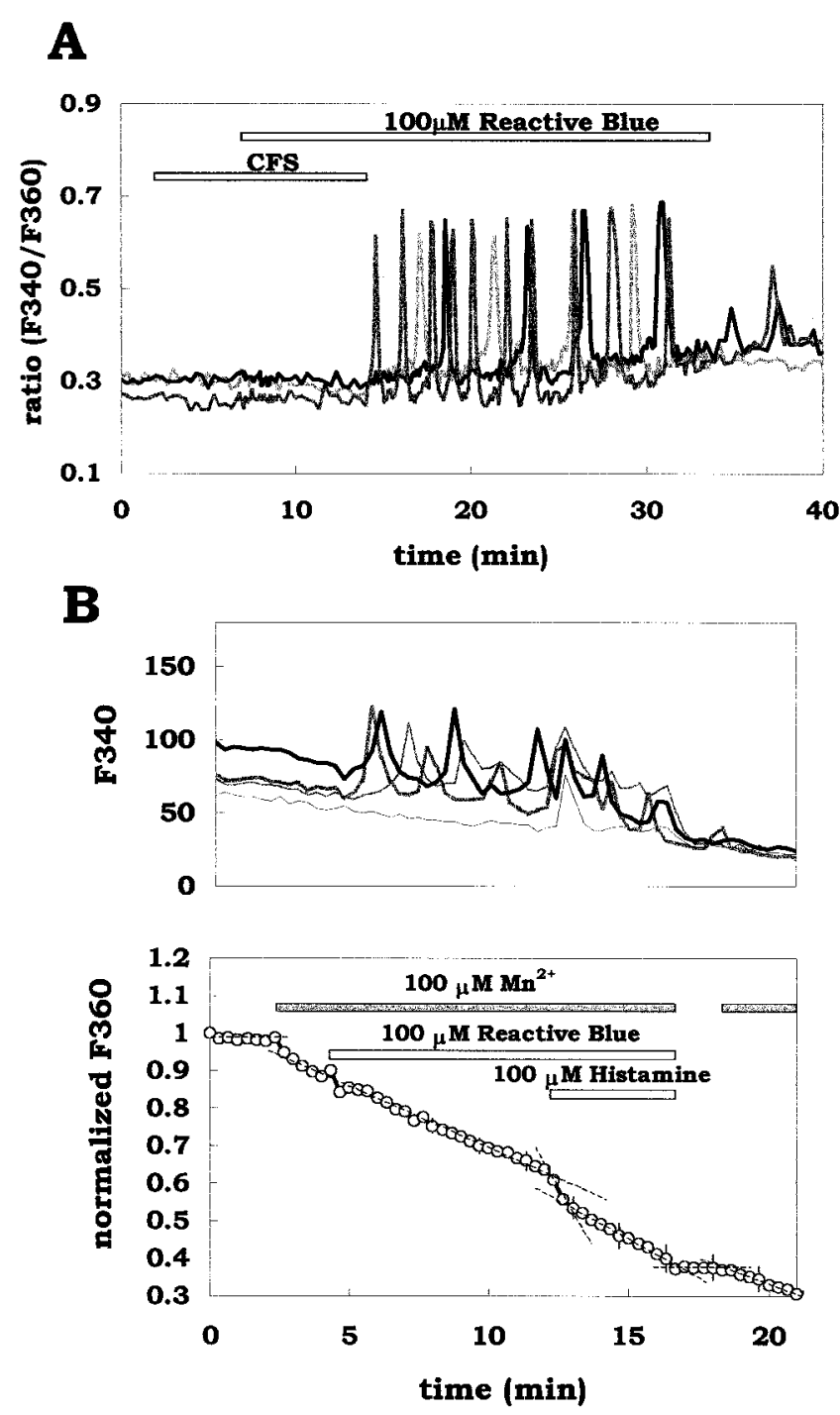

Fig. 2. Effects of extracellular $\mathrm{Ca}^{2+}$ on the RB-induced $\mathrm{Ca}^{2+}$ oscillations. A: RB-induced $\mathrm{Ca}^{2+}$ oscillations were suppressed in $\mathrm{Ca}^{2+}$-free solution (CFS). Extracellular solution was changed to CFS at 5 min before the application of $100 \mu \mathrm{M}$ RB. Three typical traces observed from 336 cells in 3 different experiments are shown. A re-addition of $\mathrm{Ca}^{2+}$ induced $\mathrm{Ca}^{2+}$ oscillations. B: $\mathrm{Ca}^{2+}$ entry, measured as quenching speed of fura-2 fluorescence on addition of 100 $\mu \mathrm{M} \mathrm{MnCl}{ }_{2}$, did not increase with the RB-induced $\mathrm{Ca}^{2+}$ oscillations. However, histamine increased the $\mathrm{Ca}^{2+}$ entry. Two fura-2 fluorescence, $F_{340}$ (upper trace; 4 typical cells), and $F_{360}$ normalized at time 0 (lower trace; average of 24 cells) are shown. Similar results were obtained in 4 different experiments.

ceased when CFS was perfused (data not shown). These findings suggest that $\mathrm{Ca}^{2+}$ entry is necessary for $\mathrm{Ca}^{2+}$ oscillations induced by $\mathrm{RB}$.

So we first considered that RB might activate a $\mathrm{Ca}^{2+}$ entry pathway. We examined whether the $\mathrm{Ca}^{2+}$ influx was increased by $\mathrm{RB}$, using $\mathrm{Mn}^{2+}$ quenching technique. Even in a resting condition, fura-2 fluorescence excited at $360 \mathrm{~nm}$ gradually quenched after 100 $\mu \mathrm{M} \mathrm{Mn}^{2+}$ was added in the solution (Fig. 2B). This indicates the existence of $\mathrm{Ca}^{2+}$ influx in the resting condition in HeLa cells. The quenching speed did not change during $\mathrm{Ca}^{2+}$ oscillations induced by RB (Fig. 2B). The slopes of quenching were $-0.029 \pm 0.0056$ before the application of $\mathrm{RB}$ and $-0.031 \pm 0.0041$ during $\mathrm{Ca}^{2+}$ oscillations induced by RB (mean \pm standard error, $n=4)$. On the other hand, an application of histamine $(100 \mu \mathrm{M})$ induced additional $\mathrm{Ca}^{2+}$ responses and increased the quenching speed significantly $\left(-0.111 \pm 0.0051^{*}\right.$ at the initial phase, and $-0.041 \pm 0.0063 *$ at the steady phase; *significant with Student's $t$ test, $p<0.05$ ) (Fig. 2B). This increase in $\mathrm{Ca}^{2+}$ influx may be due to the increase of capacitative $\mathrm{Ca}^{2+}$ entry after the histamine response. There remains a possibility that $\mathrm{Mn}^{2+}$ permeability is too low to detect by the quenching method, but the basal $\mathrm{Ca}^{2+}$ level is unaltered by the application of $\mathrm{RB}$ and the $\mathrm{Ca}^{2+}$ oscillations start without any basal $\mathrm{Ca}^{2+}$ increase (e.g., Fig. 1B). These findings suggested that RB-induced $\mathrm{Ca}^{2+}$ oscillations required $\mathrm{Ca}^{2+}$ entry but $\mathrm{RB}$ did not increase $\mathrm{Ca}^{2+}$ influx.

$\mathrm{La}^{3+}$ is an inhibitor of a certain $\mathrm{Ca}^{2+}$ entry pathway. RB-induced $\mathrm{Ca}^{2+}$ oscillations were not inhibited by an application of $1 \mu \mathrm{M} \mathrm{LaCl}_{3}$ (3 cases out of 3 experiments; not shown).

Contribution of PLC cascade. U73122 (an inhibitor of PLC; $3 \mu \mathrm{M}$ ) inhibited the occurrence of $\mathrm{Ca}^{2+}$ oscillations induced by RB (Fig. 3A), but U73343 (an inactive analogue of U73122; $3 \mu \mathrm{M}$ ) did not (Fig. 3B). Thapsigargin (an inhibitor of $\mathrm{Ca}^{2+}$ pump of the ER membrane; $1 \mu \mathrm{M}$ ) also inhibited $\mathrm{Ca}^{2+}$ oscillations (Fig. 3C). These findings indicate that not only extracellular $\mathrm{Ca}^{2+}$ entry but also $\mathrm{Ca}^{2+}$ release from the ER is necessary for $\mathrm{RB}$ to induce $\mathrm{Ca}^{2+}$ oscillations.

We tested the possibility that RB could affect an intracellular pathway leading to $\left[\mathrm{Ca}^{2+}\right]_{\mathrm{i}}$ increase. Histamine is known to induce a $\mathrm{Ca}^{2+}$ response followed by $\mathrm{Ca}^{2+}$ oscillations through the activation of G-protein, $\mathrm{PLC}$, and $\mathrm{IP}_{3}$-induced $\mathrm{Ca}^{2+}$ release [6-8]. So we used histamine as a tool to activate intracellular pathways. To avoid the effects of $\mathrm{Ca}^{2+}$ entry, $\mathrm{Ca}^{2+}$ responses to histamine were examined in CFS before and after the $\mathrm{RB}$ treatment. The $\mathrm{Ca}^{2+}$ response to histamine increased in the presence of $\mathrm{RB}$ and returned to the control level after washout of RB (Fig. 4, A and B). This indicates that the treatment with $\mathrm{RB}$ enhances $\mathrm{Ca}^{2+}$ responses to histamine.

In conclusion, a remarkable characteristic of RB-induced $\mathrm{Ca}^{2+}$ oscillations is primarily necessary for $\mathrm{Ca}^{2+}$ influx, although the activation of PLC cascades is also included. The $\mathrm{Ca}^{2+}$ influx seems to work as a 

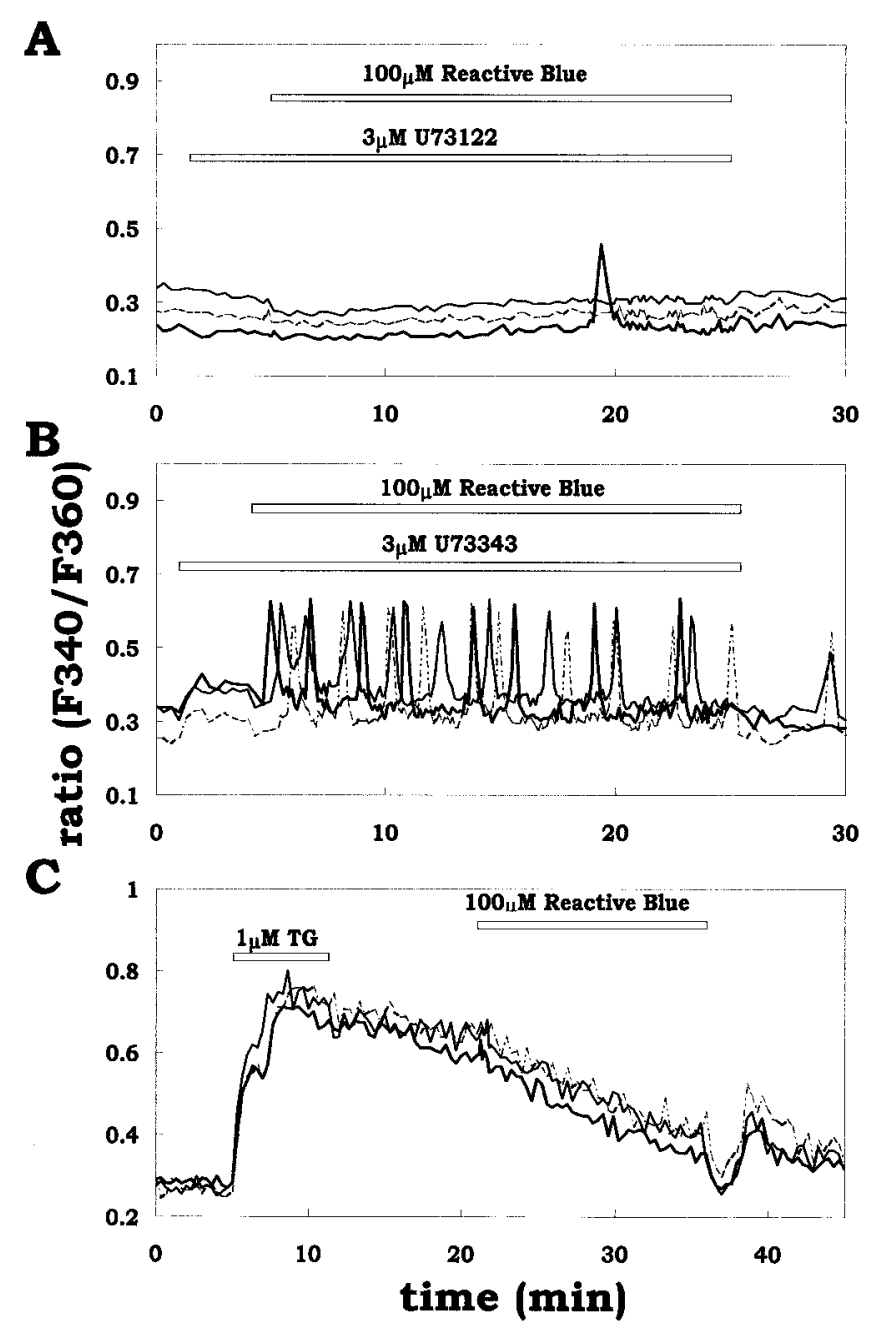

Fig. 3. Involvement of PLC cascade in RB-induced $\mathbf{C a}^{2+}$ oscillations. A: U73122 (3 $\left.\mathrm{MM}\right)$ suppressed RB-induced $\mathrm{Ca}^{2+}$ oscillations. U73122 was added at $3 \mathrm{~min}$ before the application of RB $(100 \mu \mathrm{M})$. Three typical traces observed from 224 cells in 2 different experiments are shown. B: U73343 $(3 \mu \mathrm{M})$ had no effect on RB-induced $\mathrm{Ca}^{2+}$ oscillations. C: Thapsigargin (TG; $1 \mu \mathrm{M})$ suppressed RB-induced $\mathrm{Ca}^{2+}$ oscillations. TG was added at $15 \mathrm{~min}$ before the application of RB (100 $\mu \mathrm{M})$.

trigger of the $\mathrm{Ca}^{2+}$ oscillations. This is different from $\mathrm{Ca}^{2+}$ oscillations induced by ATP or histamine, where the $\mathrm{Ca}^{2+}$ oscillations occurred even in CFS. In these cases, the $\mathrm{Ca}^{2+}$ influx works to maintain $\mathrm{Ca}^{2+}$ oscillations by replenishing the intracellular stores. In both cases, $\mathrm{Ca}^{2+}$ oscillations themselves are caused by $\mathrm{Ca}^{2+}$ release from intracellular stores. So where is the action site of RB?

We first thought that $\mathrm{RB}$ might affect the $\mathrm{Ca}^{2+}$ influx pathway because $\mathrm{RB}$-induced $\mathrm{Ca}^{2+}$ oscillations required extracellular $\mathrm{Ca}^{2+}$. However, this is unlikely because $\mathrm{Ca}^{2+}$ influx measured with the $\mathrm{Mn}^{2+}$ quenching method did not increase and no basal increase of $\mathrm{Ca}^{2+}$ was observed on $\mathrm{RB}$ treatment.
$\mathbf{A}$

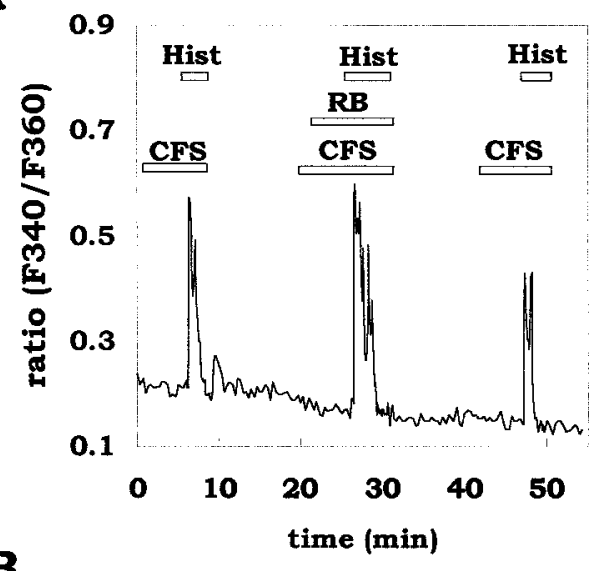

$\mathbf{B}$

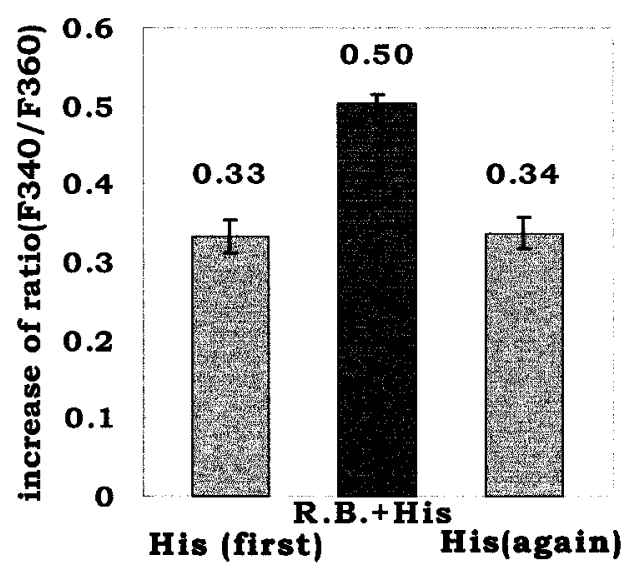

Fig. 4. Enhancement of PLC pathway by RB. Treatment with $\mathrm{RB}(100 \mu \mathrm{M})$ enhanced the $\mathrm{Ca}^{2+}$ response to histamine $(100 \mu \mathrm{M})$. Responses to histamine were measured at 5 to 6 min after CFS perfusion and at 4 min after RB treatment. A: Data are shown by a typical trace. B: Changes of peak increase of $\mathrm{Ca}^{2+}$ on average (84 cells) with RB (100 $\mu \mathrm{M})$ treatment and after washout. Error bars indicate standard error. The increase induced by RB treatment was significant with a $p$-value of less than 0.001 by Student's $t$ test. Similar results were obtained in 3 different experiments.

We next considered that RB might affect the PLC pathway because U73122 and thapsigargin inhibited $\mathrm{Ca}^{2+}$ oscillations. In fact, $\mathrm{RB}$ enhanced $\mathrm{Ca}^{2+}$ responses to histamine. Histamine induces a $\mathrm{Ca}^{2+}$ response through the activation of the $\mathrm{H}_{1}$-receptor, $\mathrm{G}$ protein, $\mathrm{PLC}$, and $\mathrm{IP}_{3}$ receptor [6-8]. Our data suggest that RB acts upstream of PLC, i.e., on receptors, $G$ protein, or PLC. However, RB did not activate these processes like the agonists did, because RB-induced $\mathrm{Ca}^{2+}$ oscillations required $\mathrm{Ca}^{2+}$ influx to trigger, while the $\mathrm{Ca}^{2+}$ oscillations induced by receptor activation of histamine or ATP could occur even in CFS. Among these processes, PLC is known to be regulated by $\mathrm{Ca}^{2+}$ [17]. Actually in HeLa cells, extracellular $\mathrm{Ca}^{2+}$ affected the frequency of $\mathrm{Ca}^{2+}$ oscillations through $\mathrm{Ca}^{2+}$-stimulated activation of PLC [8]. Although the 
mechanism of $\mathrm{Ca}^{2+}$-regulation of PLC is not well understood, an isoenzyme PLC $\delta$ was reported to be activated by $\mathrm{Ca}^{2+}[18]$.

So a plausible action site of $\mathrm{RB}$ to induce $\mathrm{Ca}^{2+}$ oscillations in HeLa cells is the PLC. RB may enhance the $\mathrm{Ca}^{2+}$ sensitivity of PLC, making it possible to activate PLC with a small influx of $\mathrm{Ca}^{2+}$ that exists even in the resting condition. The activation of PLC causes $\mathrm{IP}_{3}$ production and release of $\mathrm{Ca}^{2+}$ from intracellular stores. Further investigations, such as direct measurements of PLC activity or fluorescent analysis using the PH domain of PLC, should help to confirm our model.

RB has been used as a blocker of ATP receptors [9, $10]$, but there are also reports that RB blocks some channels and receptors [11-15]. Besides these inhibitory actions of $\mathrm{RB}$, we here demonstrated that RB had a stimulatory action on the PLC cascade. Our results show not only that one should be careful when using RB as a blocker of ATP receptors, but also that it might be interesting to use RB as a tool for an investigation of the 'endogenous' activation of $\mathrm{Ca}^{2+}$ oscillations.

This work was partly supported by Grants-in-Aid for Scientific Research from the Ministry of Education, Science, Sports and Culture of Japan to K. F. and T. K., by CREST of Japan Science and Technology Corporation to K. F., and by a Sasakawa Scientific Research Grant from the Japan Science Society to $\mathrm{A}$. O.

\section{REFERENCES}

1. Berridge MJ: Inositol trisphosphate and calcium signalling. Nature 361: 315-325, 1993

2. Dolmetsch RE, Xu K, and Lewis RS: Calcium oscillations increase the efficiency and specificity of gene expression. Nature 392: 933-936, 1998

3. Li W, Llopis J, Whitney M, Zlokarnik G, and Tsein RY: Cell-permeant caged $\mathrm{InsP}_{3}$ ester shows that $\mathrm{Ca}^{2+}$ spike frequency can optimize gene expression. Nature 392: 936-941, 1998

4. Hajnozky G, Robb-Gaspers LD, Seitz MB, and Thomas AP: Decoding of cytosolic calcium oscillations in the mitochondria. Cell 82: 415-424, 1995

5. Evans JH and Sanderson MJ: Intracellular calcium oscillations regulate ciliary beat frequency of airway epithelial cells. Cell Calcium 26: 103-110, 1999
6. Tilly BC, Tertoollen LG, Lambrechts AC, Remorie R, de

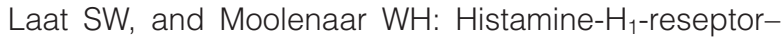
mediated phosphoinositide hydrolysis, $\mathrm{Ca}^{2+}$ signalling and membrane-potential oscillations in human HeLa carcinoma cells. Biochem J 266: 235-243, 1990

7. Sauve R, Diarra A, Chahine M, Simoneau C, Morier N, and Roy $\mathrm{G}$ : $\mathrm{Ca}^{2+}$ oscillations induced by histamine $\mathrm{H}_{1}$ receptor stimulation in HeLa cells: Fura-2 and patch clamp analysis. Cell Calcium 12: 165-176, 1991

8. Bootman MD, Young KW, Young JM, Moreton RB, and Berridge MJ: Extracellular calcium concentration controls the frequency of intracellular calcium spiking independently of inositol 1,4,5- trisphosphate production in HeLa cells. Biochem J 314: 347-354, 1996

9. Reilly WM, Saville VL, and Burnstock G: An assessment of the antagonistic activity of reactive blue 2 at P1- and P2-purinoceptors: supporting evidence for purinergic innervation of the rabbit portal vein. Eur $\mathrm{J}$ Phamacol 140: 47-53, 1987

10. Abbracchio MP and Burnstock G: Purinoceptors: are there families of P2X and P2Y purinoceptors? Pharmacol Ther 64: 445-475, 1994

11. Nakazawa K, Inoue K, Ito K, Koizumi S, and Inoue K: Inhibition by suramin and reactive blue 2 of GABA and glutamate receptor channels in rat hippocampal neurons. Naunyn Schmiedebergs Arch Pharmacol 351: 202-208, 1995

12. Peoples RW and Li C: Inhibition of NMDA-gated ion channels by the P2 purinoceptor antagonists suramin and reactive blue 2 in mouse hippocampal neurons. $\mathrm{Br}$ J Phamacol 124: 400-408, 1998

13. Zegarra-Moran $O$ and Galietta LJV: Biophysical characteristics of swelling-activated $\mathrm{Cl}^{-}$channels in human tracheal 9HTEo-cells. J Membrane Biol 165: 255-264, 1998

14. Conghlan SJ, Davenport JW, and Hind G: Reactive Blue 2 is a potent inhibitor of a thylakoid protein kinase. Eur J Biochem 197: 467-471, 1991

15. Maruyama K: Interaction of 4-carboxy-2-hydroxymuconate-6-semialdehyde dehydrogenase with Reactive Blue 2 and related dyes. J Biochem 103: 714-721, 1988

16. Furuya K, Enomoto K, and Yamagishi S: Spontaneous calcium oscillations and mechanically and chemically induced calcium responses in mammary epithelial cells. Pflügers Arch 422: 295-304, 1993

17. Cockcroft $\mathrm{S}$ and Thomas $\mathrm{MH}$ : Inositol-lipid-specific phospholipase $\mathrm{C}$ isoenzymes and their differential regulation by receptors. Biochem J 288: 1-14, 1992

18. Allen V, Swigart P, Cheung R, Cockcroft S, and Katan M: Regulation of inositol lipid-specific phospholipase $\mathrm{C} \delta$ by changes in $\mathrm{Ca}^{2+}$ ion concentrations. Biochem $\mathrm{J}$ 327: 545-552, 1997 